\title{
PERSPEKTIF MAHASISWA PGSD TERHADAP MATAKULIAH ADAT MELAYU DALAM MELESTARIKAN BUDAYA MELAYU JAMBI
}

\author{
Destrinelli, Alirmansyah,Kiki Handayani, Aldo Darmawan, Khaini Hajar, \\ M.Fadjar Dewangga Suri,Dina Hermina Unai \\ Universitas Jambi \\ destrinelli@unja.ac.id \\ alirmansyah@unja.ac.id \\ Kikihandayani1513@gmail.com \\ xiomi.ffc@gmail.com \\ khaini.hajar109@gmail.com \\ m.fadjardewanggasuri@gmail.com
}

\begin{abstract}
Abstact
This research was conducted to describe the perspective of PGSD students towards Malay traditional subjects in preserving the Malay culture of Jambi. This research was conducted in October to December 2019. This research was a descriptive qualitative study. The subjects in this study were PGSD University of Jambi students, data collection in this study using observation, interviews, and documentation. The results of a study of PGSD Jambi University students showed that in the Jambi Malay customary course, students fully supported the Malay customary course program in preserving the Malay culture in Jambi. But there are still many shortcomings in preserving this matter, namely from the lack of facilities and infrastructures that are still inadequate and also the schedule of other solid courses so as to give a time limit for students in preserving Jambi culture.
\end{abstract}

Keywords: the perspective of PGSD students, Malay culture of Jambi, preserving

\section{PENDAHULAN}

Provinsi Jambi memiliki luas wilayah 50.058,16 km2 dengan jumlah penduduk 3.406.178 jiwa. Memiliki banyak suku yang mendiaminya, di antaranya adalah suku kerinci, suku kubu, suku batin, suku Melayu, dan beberapa suku minoritas lainnya.Suku-suku tersebut menyebar di 9 kabupaten, 2 kota, 138 kecamatan, 163 kelurahan, dan 1.398 desa, yang umumnya mendiami di wilayah pinggiran sungai batang hari sebagai pusat perekonomian dari masa lalu hingga masa sekarang (menurut sumber permendagri Nomor 39 Tahun 2015). Jauh sebelum abad masehi etnis Melayu setelah mengembangkan suatu corak kebudayaan Melayu pra-sejarah di wilayah pegunungan dan dataran tinggi. Masyarakat pendukung kebudayaan Melayu pra-sejarah adalah suku Kerinci dan suku Batin. Orang Kerinci diperkirakan telah menepati caldera danau Kerinci sekitar tahun 10.000 SM Sampai tahun 2000 SM. Suku Kerinci dan termasuk juga suku Batin adalah suku tertua di Sumatera. Mereka telah mengembangkan kebudayaan batu seperti kebudayaan Neolitikum.

Kehadiran agama Budha sekitar abad $4 \mathrm{M}$ telah mendorong lahir dan berkembang suatu corak kebudayaan Buddhis. Kebudayaan tersebut diidentifikasikan sebagai corak kebudayaan Melayu kuno. Masyarakat pendukung kebudayaan Melayu Buddhis yang masih ada di Jambi adalah suku anak dalam (kubu). Peninggalan momental kebudayaan Melayu Buddishis adalah bangunan candi-candi yang tersebar di 


\section{5 | JURNAL ILMU BUDAY}

kawasan daerah aliran Sungai Batanghari, salah satu di antaranya adalah situs candi muara Jambi. Kebudayaan Buddhis sedang mengalami kemunduran sekitar abad 11-14 M, maka bersamaan dengan waktu itu, di daerah Jambi mulai berkembang suatu corak kebudayaan Islam. Kehadiran Islam diperkirakan pada abad $7 \mathrm{M}$ dan sekitar abad 11 M Islam mulai menyebar ke seluruh lapisan masyarakat pedalaman Jambi. Dalam penyebaran Islam ini maka pulau berhala di pandang sebagai pulau yang sangat penting dalam sejarah Islam di Jambi. Karena sejarah mencatat bahwa dari pulau berhala itulah agama Islam disebarkan keseluruh pelosok daerah Jambi. Kehadiran Islam ini membawa perubahan mendasar bagi kehidupan sosial masyarakat Melayu Jambi. Agama Islam pelan-pelan tapi pasti, mulai mengeser kebudayaan Melayu buddhis sampai berkembangnya corak kebudayaan Melayu Islam.

Terjadinya asimilasi antara kebudayaan tua di provinsi Jambi dengan hadirnya kebudayaan baru menjadikan pergeseran nilai-nilai kebudayaan itu sendiri, yang mana setiap kebudayaan itu bersifat dinamis akan perubahan, bahkan mungkin hilang sama sekali. Penyebabnya adalah perkembangan kebudayaan, pengaruh budaya luar, kurangnya kesadaran masyarakat, dan lemahnya jiwa kebudayaan para remaja sebagai generasi penerus nilai-nilai kebudayaan yang telah terjadi di Provinsi Jambi dari masa ke masa.

Dengan adanya perubahan ini yang mengarah ke era globalisasi atau abad 21 di mana setiap kebudayaan yang ada membaur dan tertutupi oleh suatu keadaan yang universal. Setiap budaya yang ada tergantikan dengan budaya budaya lain lebih menarik muncul di internet dan munculnya budaya budaya baru yang menggerus budaya lama dan menggantikannya yang mana seperti yang kita ketahui bisa membuat kehilangan indentitas dari ciri khas budaya kita . Selanjutnya seperti budaya budaya hedoisme ataupun budaya budaya yang meniru kebarat-baratan yang tidak sesuai dengan budaya Indonesia yang lebih kearah timur.

Universitas Jambi sebagai salah satu wadah pendidikan terbesar di provinsi Jambi sudah mengantisipasi nya dengan menerapkan suatu sistem pembelajaran yang mengedepankan budaya budaya yang ada di provinsi Jambi sehingga tidak tergerus oleh kemajuan jaman. Salah satu cara yang digunakan universitas Jambi yang terealisasi di salah satu prodi yaitu prodi pendidikan guru sekolah dasar dengan menerapkan pembelajaran matakuliah adat melayu Jambi yang di usahakan dapat melestarikan adat melayu Jambi di kalangan mahasiswa.

Munculnya sistem ini tidak selalu adanya kemudahan dan penerimaan secara langsung oleh khalayak ramai tentu ada yang pro dan kontra. Disini peneliti ingin mengetahui pandangan dari sisi mahasiswa tentang adanya matakuliah adat melayu Jambi yang mana bertujuan untuk melestarikan budaya Jambi. Apakah dengan adanya matakuliah ini memang terjadi pelestarian budaya Jambi dikalangan mahasiswa atau matakuliah ini hanya sebatas matakuliah tentunya semua akan terjawa dengan keadaan di nlapangan nantinya.

Penelitian yang hampir sama dengan penelitian ini adalah penelitian yang dilakukan oleh alirmansyah yang berjudul "Persepsi Mahasiswa PGSD Universitas Jambi Terhadap Mk Tari Melayu Jambi". Penelitian ini bertujuan mengkaji dan mendeskripsikan Persepsi Mahasiswa PGSD Universitas Jambi Terhadap MK Tari Melayu, penelitian diharapkan mampu menemukan persepsi yang tepat terhadap MK tari melayu oleh Mahasiswa PGSD. Penelitian ini 
menggunakan pendekatan kualitatif. Data dikumpulkan menggunakan observasi, wawancara, dan dokumentasi. Hasil penelitian ini menunjukkan bahawa dalam pandangan mahasiswa PGSD pada awalnya tari melayu Jambi sangatlah sulit namun dikarenakan proses pembelajaran tari melayu Jambi itu sendiri asik maka membuat mahasiswa semangat mengikuti proses yang terbukti dengan berbagaiprestasi yang di raih mahasiswa Pendidikan Guru Sekolah Dasar, selain prestasi yang diraih mahasiswa juga mampu mengemangkan potensi dirinya di sekolah dasar untuk mampu mengajar tari melayu Jambi kepada peserta didik yang ada.

Dengan permasalahan yang di jelaskan diatas peneliti ingin melakukan penelitian yang berjudul perspektif mahasiswa PGSD terhadap matakuliah adat melaju Jambi dalam melestarikan budaya melayu Jambi.

\section{METODE}

Penelitian kualitatif adalah penelitian yang memakai latar alamiah, dengan maksud menerangkan fenomena yang terjadi dan dilakukan dengan jalan yang mengaitkan berbagai metode yang ada. Desain pendekatan penelitian ini sesuai dengan jenis permasalahan yang diajukan. Dalam penelitian ini digunakan desain pendekatan naturalistik. Dimana pendekatan naturalistik ini untuk mencari dan mendapatkan pengertian atau pemahaman tentang gejala dalam suatu latar yang berkonteks khusus.

Adapun alasan peneliti dalam menggunakan pendekatan naturalistik ini, karena dalam pendekatan naturalistik lebih meneliti tentang pemahaman tentang pandangan dalam suatu latar yang khusus. Di mana dalam penelitian ini nantinya akan memberi informasi tentang perspektif mahasiswa PGSD terhadap matakuliah adat melayu dalam melestarikan budaya melayu Jambi.

Pada penelitian ini peneliti menggunakan pendekatan naturalistik di mana data yang peneliti dapatkan benarbenar data yang peroleh dari hasil penelitian peneliti di lapangan. Kemudian data tersebut dikumpulkan dan diolah untuk dibuat ke dalam hasil penelitian peneliti.

Subjek penelitian ini adalah mahasiswa PGSD. Dalam penelitian ini, peneliti melakukan penelitian di sekitar balai adat melayu Jambi, tetapi tidak semua mahasiswamenjadi subjek penelitian. Peneliti hanya melakukan penelitian pada berberapa masyrakat sekitar yang tinggal di wilayah balai adat kota Jambi. Jadi pada penelitian ini peneliti mengambil sampel dari berberapa mahasiswasekitar sebagai subjek penelitian, alasan peneliti mengambil mahasiswa PGSD karena mahasiswa lebih tau dan mengalami pembelajaran tentang matakuliah adat melayu Jambi.

Pengumpulan data dapat dilakukan dengan cara alamiah (natural setting). Teknik pengumpulan data dapat dilakukan menggunakan teknik wawancara, observasi, dan dokumentasi.

Observasi atau pengamatan adalah instrumen pengumpulan data yang dilakukan dengan cara mengamati dan mencatat secara sistematik fenomenafenomena yang diselidiki. Dalam pengertian lain disebutkan bahwa metode observasi atau disebut dengan pengamatan adalah kegiatan pemusatan atas suatu obyek dengan menggunakan seluruh panca indra.

Metode ini dilakukan dengan cara mengadakan pengamatan langsung terhadap objek kemudian hasil pengamatan tersebut dituangkan dalam sebuah catatan. Adapun yang menjadi fokus pengamatan dalam penelitian ini adalah tentang disiplin belajar . 


\section{7 | JURNAL ILMU BUDAYA}

Volume 8, Nomor 1, Juni 2020

Dalam penelitian kualitatif naturalistik, peneliti biasanya melakukan berbagai wawancara mendalam dengan berbagai pihak. Wawancara dapat dilakukan secara formal atau direncanakan , dan dapat juga dilakukan secara informal tidak menggunakan catatan dan bentuk yang tertentu. Dalam wawancara itu yang terpenting adalah terciptanya suasanya yang akrab dan santai. Wawancara naturalistik yang mendalam hampir sama dengan pembicaraan yang akrab tersebut, sehingga peneliti dapat memanfaatkan pendekatan ini untuk mengumpulkan data selengkap-lengkapnya disamping observasi.

Jenis wawancara yang dipakai dalam penelitian ini adalah wawancara terstruktur, yakni wawancara yang pewancaranya memastikan sendiri masalah dan pertanyaan-pertanyaan yang akan diajukan. Pertanyaan-pertanyaan yang ada dalam wawancara jenis ini disusun dengan rapi dan padat.

Teknik wawancara difokuskan peneliti untuk menggali dan mendapatkan data-data yang diperlukan dalam penelitian ini. Wawancara dilakukan dengan, mahasiswa PGSD Universitas Jambi.

Dokumen merupakan catatan peristiwa yang sudah berlaku. Dokumen bisa berupa tulisan, gambar, atau karyakarya monumental dari seseorang. Dokumen yang berupa video dan gambar dokumen merupakan pelengkap dari pemakaian metode observasi dan wawancara dalam penelitian kualitatif.

Metode dokumentasi yang peneliti pakai untuk mengumpulkan data tertulis yang diperlukan oleh peneliti terkait perspektif mahasiswa PGSD terhadap matakuliah adat melayu dalam melestarikan budaya melayu Jambi.

\section{HASIL DAN PEMBAHASAN}

Berdasarkan hasil observasi yang dilakukan oleh peneliti mengenai perspektif mahasiswa PGSD terhadap matakuliah adat melayu dalam melestarikan budaya melayu Jambi, sebagian besar mahasiswa ikut mendukung adanya program matakuliah adat melayu Jambi melalui proses perkuliahan yang di dalam kegitannya banyak sekali praktek yang dapat membuat mahasiswa tertarik dalam mempelajari dan mengenal budaya melayu Jambi. Pada observasi peneliti menemukan mahasiswa sebagian besar ikut aktif dalam setiap proses perkuliahan, katif dalam praktek praktek perkuliahan, ikut serta dalam kegiataqn berbau adat melayu Jambi dan mengikuti tata tertib matakuliah adat melayu Jambi

Berdasarkan hasil wawancara yang telah dilakukan mengenai perspektif mahasiswa PGSD terhadap matakuliah adat melayu dalam melestarikan budaya melayu Jambi tersebut yaitu sebagai berikut Mata Kuliah Adat Melayu Jambi dapat menambahkan pengetahuan, wawasan dan pengalaman melalui budaya Jambi selain itu, mata kuliah adat melayu Jambi dapat melestarikan Kebudayaan Melayu Jambi dengan kegiatan mencaritahu peninggalan-peninggalan sejarah Jambi, dengan mengunjungi tempat peninggalan budaya Jambi, mata kuliah adat melayu Jambi juga memberikan pengaruh yang positif terhadap mahasiswa PGSD dengan pembiasaan menggunakan baju adat melayu Jambi pada saat matakuliah adat melayu Jambi. dengan pembiasaan menggunakan baju adat melayu Jambi sehingga mahasiswa yang sebelumnya merasa asing untuk menggunakan baju adat melayu sekarang menjadi terbiasa bahkan menggemari baju melayu Jambi. selama prosesnya, mahasiswa antusisas 


\section{8 | JURNAL ILMU BUDAYA}

Volume 8, Nomor 1, Juni 2020

dalam mendalami materi-materi yang yang dibahas selama pembelajaran.

Pada setiap prosesnya matakuliah adat melayu Jambi telah berupaya dalam melestarikan budaya melayu Jambi dengan mengunjungi balai adat dan mendapatkan pemngetahuan batu dengan perbincangan bersama datuk yang bertanggung jawab terhadap balai adat. Selain memiliki banyak kelebihan terdapat juga kendala dalam perkuliahan adat melayu Jambi yaitu kurangnya sarana dan prasaranna dan jadwal perkuliahan yang sering bertumburan. Mata kuliah ada melayu Jambi memberikan banyak manfaat bagi mahasiswa PGSD sehingga mahasiswa banyak tahu mengenai adat Jambi.

Dari segi Sarana dan prasarana penunjang perkuliahan adat melayu Jambi masih dikategorikan kurang lengkap contonya untuk kegiatan membatik dikampus belum disediakan sarana dan prasarana membatik dan dengan begini mahasiswa diarahkan untuk mencari tahu sendiri dengan mengunjungi tempat-tempat membatik yang terdapat di Jambi contohnya di kota seberang untuk mengamati dan mempelajari apa itu batik Jambi dan bagaimana cara membatik. Dengan adanya mata kuliah adat melayu Jambi mahasiswa ikut berperan dalam melesatrikan budaya melayu Jambi salah satunya dengan memakai baju adat melayu atau biasa disebut baju kurung selama perkuliahan berlangsung. Dalam kesehariannya mahasiswa PGSD sudah mencerminkan sikap masayarakat melayu Jambi dengan makan berawang yang dalam kegiatannya dilakukan dengan cara berkumpul untuk makan bersama teman-teman sehingga dapat menjalin silaturahmi antar sesama. Dengan adanya perkuliahan ini diharapkan dapat melestarikan budaya melayu Jambi, mahasiswa lebih bisa berpartisipasi dalam memunculkan kembali budaya budaya yg hamper di kikis zaman, mahasiswa lebih mencinta budaya daerah melayu Jambi sebagai pusat daerah dimana mereka berkuliah.

\section{KESIMPULAN}

Berdasarkan hasil penelitian yang dilakukan oleh peneliti mengenai perspektif mahasiswa PGSD terhadap matakuliah adat melayu dalam melestarikan budaya melayu Jambi, di simpulkan bahwa setiap mahaiswa memiliki pendapat yang berbeda dan beragam mengenai matakuliah adat melayu dalam melestarikan budaya melayu Jambi. Dilihat secara keseluruhan, mahasiswa lebih banyak mennyatakan kesetujuan mereka dengan program matakuliah adat melayu Jambi di karenakan banyak hal positif di dalamnya berkaitan dengan pelerstarian budaya melayu Jambi.

Upaya pihak kampus yang menyelenggarakan program ini untuk melestarikan budaya Jambi di kalangan mahasiswa sungguh patut di apresiasi dengan sambutan yang bagus dari mahasiswa walaupun tidak sedikti yang menyatkan ketidaksetujuan mereka karena adanya proses yang sulit dihadapi karena banyaknya praktek di dalam program ini.

\section{DAFTAR PUSTAKA}

Sundari, K. 2018. Persepsi Guru Terhadap Kearifan Lokal di Sekolah Dasar.

Lexy J. Moleong. 2010. Metode Penelitian Kualitatif. Bandung: Remaja Rosdakarya

Sadzali, A. M., \& Anra, Y. (2018). Ragam Arsitektur Rumah Tradisional Melayu Jambi: Suatu Kajian Arkeologi Arsitektur Dalam Upaya Pelestarian Warisan Budaya Dan Pemajuan Kebudayaan Melayu Jambi. Jurnal Ilmu Humaniora, 2 (02). 
Alirmansyah, A., Destrinelli, D., Sargandi, M., Yolanda, S., Wisudawati, N., Samosir, W. L. S., ... \& Nurlayly, C. 2019. Persepsi Mahasiswa PGSD Universitas Jambi Terhadap MK Tari Melayu Jambi. JPKS, Jurnal Pendidikan dan Kajian Seni). Vol 4. (2), 165-183.

Baidawi, A., \& Dewi, R. 2019. Sosisalisasi Pelestarian Budaya Daerah Untuk Generasi Muda Di Sman 5 Kota Jambi. Rambideun: Jurnal Pengabdian Kepada Masyarakat, Vol. 2 (2).

Sanusi, I. 2017. Globalisai Melayu: Peluang dan Tantangan Membangun Identitas Melayu dalam Konteks Modernitas. Tarbawiyah: Jurnal Ilmiah Pendidikan. Vol. 1 (1), 3957.

Sadzali, A. M., \& Anra, Y. 2018. Ragam Arsitektur Rumah Tradisional Melayu Jambi: Suatu Kajian Arkeologi Arsitektur Dalam Upaya Pelestarian Warisan Budaya Dan Pemajuan Kebudayaan Melayu Jambi.Titian: Jurnal Ilmu Humaniora, Vol. 2 (02), 300-322.

Muslim, F. (2015). Analisis perkembangan perubahan budaya masyarakat kota jambi dan pengembangan pola perekonomian masyarakat berbasis ekonomi kreatif. In Prosiding Seminar Nasional Profesionalisme Pendidik dalam Dinamika Kurikulum Pendidikan di Indonesia pada Era MEA UNY. Yogyakarta, 9 Mei 2015. pp. 789-796. 